\title{
Increase Brand Value of Higher Education Institution
}

\author{
Puspo Dewi Dirgantari, Agus Rahayu, Disman, Ratih Hurriyati \\ Sekolah Pascasarjana \\ Universitas Pendidikan Indonesia \\ Bandung, Indonesia \\ dewiez_thea@yahoo.co.id
}

\begin{abstract}
Universities in Indonesia are dominantly located in the province of West Java and Banten. However, the number of students in West Java has decreased. Moreover, as competition among universities is getting tighter, ranking universities in West Java have decreased in the world and/or Asia. These show that brand value of higher education in West Java is still not optimal. The assessment processes itself, enrich the organization with a much more comprehensive understanding of their customers, markets and channels, the competitive environment, and operational capabilities. This study uses the science of marketing management approach. The method used in this research is descriptive survey and explanatory survey. The data used are primary data and secondary data collected through questionnaires and documentation media. Structural Equation Modelling was used to measure the impact of brand element and marketing mix of educational services to the brand value of higher-education institutions. This study is part of my dissertation.
\end{abstract}

Keywords-Brand Element; Marketing Mix of Education Services; Brand Value

\section{INTRODUCTION}

Higher education is one important pillar that is expected to bring a change in a nation, because the nature of higher education is honed and use someone's reasoning in solving the problems that faced. Higher-education present as a reasoning environment to humanize the people in accordance to the image of man [1].

There is an intense competition among institutions of university campuses. In the urban area alone there are about 10 to 15 higher-education institutions. With so many options, the question is how prospective students choose a college? [2]. Every year universities in Indonesia continue to increase in numbers. In 2005 amounted to 2.428 universities, colleges rose to 3,216 in 2012. This increase was impacted on the increasing competition among the college itself.

TABLE I. NUMBER OF UNIVERSITIES IN INDONESIA YEAR 2005 - 2012

\begin{tabular}{|c|c|}
\hline Year & The Numbers of Universities \\
\hline 2005 & 2.428 \\
\hline 2006 & 2.581 \\
\hline 2008 & 2.929 \\
\hline 2010 & 3.098 \\
\hline 2012 & 3.216 \\
\hline
\end{tabular}

Location universities in Indonesia to the local level, predominantly in the area of West Java and Banten provinces with the proportion of $15.6 \%$ of universities throughout Indonesia with the ownership status of State Universities (PTN) and Private Universities (PTS) [4], but the number of students in higher education in West Java have decreased.

TABLE II. Number of PRIVATE UnIVERSity Students IN WeSt JAVA YEAR 2009 - 2013

\begin{tabular}{|c|c|}
\hline Year & The Number of College Student \\
\hline 2009 & 398.466 \\
\hline 2010 & 230.564 \\
\hline 2011 & 484.781 \\
\hline 2012 & 520.023 \\
\hline 2013 & 387.628 \\
\hline
\end{tabular}

c. (Source: Processed Data)

The number of students at private universities in West Java in 2009, as many as 398466 students dropped to 230564 students in 2010. In 2011 increased 484781 students and 520 023 students, but decreased again in 2013 to 387628 students [5].

The ups and downs of the number of PTS students in West Java are caused by various factors. In 2013, about 55 private universities (PTS) in West Java were in critical condition because it has a few students. Even in one of the university, the number of student they have are only 50 people, it is very difficult to ensure the sustainability of PTS, because PTS survival depends on the funds from student and its foundations. If admissions are low, it is difficult for the PTS to develop. One of the causes PTS difficult to obtain a student, because state university (PTN) is accepting too many new students. One State university could receive up to 10,000 new students [6].

TABLE III. Number OF PUbliC UNIVERSITy StUdENTS IN WEST JAVA YEAR 2005 - 2011

\begin{tabular}{|c|c|}
\hline Year & The Number of College Students \\
\hline 2005 & 27.700 \\
\hline 2006 & 39.400 \\
\hline 2007 & 59.400 \\
\hline 2008 & 80.600 \\
\hline 2009 & 121.255 \\
\hline
\end{tabular}

The number of students at the College of West Java, from the year 2005 - 2010 has increased but declined in 2011. In 2010 as many as 181055 students dropped to 112191 students. This shows that the favorite PTN is not necessarily always in 
the good position, because it has favorite status, and they always selected the best students, so as to produce graduates who are skilled, intelligent, insightful and reliable is not difficult. These make PTN swayed and did not attempt to make any changes to compete nationally and internationally[7].

According to Laksono Trisnantoro, based on five years of observations at universities, colleges, both local and abroad, there are some findings that can be highlighted, such as:

- There are artifacts that show the lack of full support for the faculty: e.g. labs should seek their own funds, and lecturers who were not given the standards working facility, revenue is not yet clear, and so on,

- Lecturer in Indonesia does not have a strong culture to work as a lecturer,

- The tradition of multi faculty working together remain not seen. This can be seen, for example, from the low interconnection between science, there is no professor of medical anthropology, or philosophy of medicine, or health economics, where it has become a common thing in leading universities abroad,

- Organizational culture of state universities has not put the knowledge-based culture where research and development of science is considering as important,

- The Dean and Rectorate have not become a supportive leader for lecturers. The development and condition of Rectorate are very uneven with the development of the units or laboratories in the faculty [8].

While Supra Wimbarti found problems facing colleges associated with:

- In developed countries, the publication culture is high, "publish or perish." At universities in Indonesia, this culture is still very weak even when compared to be other developing countries. For example, the faculty of biology Kelaniya University in Sri Lanka, has a high index of publication, it is supported by a complete laboratory facility at the faculty.

- Independency in developing science, academic freedom and freedom of academic forum.

- Collegial culture. Unlike in companies where the relationship between the leadership and the staff is hierarchical; the relationship between the rector and dean of the college is collegial. There is a rotation of leadership, the chancellor one day will become a regular lecturer staff again, and to become a colleague again.

- Self-management. Many lecturers who still behave like obedient workers. They $h$ less the initiative, both in structural and functional. This should be changed through a top-down reform.

- In connection with the role of Tridarma. In other countries, there is no requirement of the third point Tridarma which is the community service. In
Indonesia, it must be established with consistently. However, Tridarma should be applied fairly, in terms of lecturers who 'developing' organization, for example, holding structural positions should be given its own assessment as perform the third functions of Tridarma, because while serving as an official, he could not perform others function of Tridarma, namely research or teaching,

- There is a necessity to design human-resource development. If there are lecturers who will continue their education at the doctoral level, should be asked in what areas will he/she studied? It should correspond to the development of science in each faculty, and it's should be in accordance with strategic planning of faculty,

- Is a world-class university can be realized with a culture like this? A research university should be able to produce 100 doctors in one year, and we have not reached there. How about choosing the rector / dean, is it merit based? Then from the academic side, as a research university, whether we want all of the academic based or vocational-based? UGM opens its program start from D1 through S3 [9].

At the time of competition among universities is getting tighter, universities rank in Indonesia-especially in West Java declined in the eyes of the world, including in Asia. Though implicitly The Education Minister Bambang Sudibyo (Cabinet 2004-2009) states that the definition of quality of a campus is not to be seen from the results of the competition between the campus with other campuses. The logic flow used is a worldclass campus that has a good ranking in the competition, and competition level is the international competition.

Meanwhile, Vice Chancellor for Academic and Student Affairs, Yonny Koesmaryono stated that in order to enter a world-class university, these 50 leading universities in Indonesia, must gain international recognition through international accreditation. International recognition of a university will have a positive impact on the performance of each unit that must always perform excellent performance. The statement also indicates the need to enter the campus in the global arena and then assessed for recognition of international agencies [10].

Based on the QS World University Ranking 2014/2015, the highest Indonesian universities were ranked 310, the University of Indonesia, followed by Bandung Institute of Technology ranked 462-470, Gajah Mada University ranked in the 551-600 and 701+ world rankings occupied Airlangga University, Bogor Institute of Technology, University of Diponegoro, Ten November Institute of Technology, and University of Brawijaya [11]. Indonesian University rankings in Asia are presented in Table IV below: 
TABLE IV. INDONESIAN UNIVERSITY RANK BASED ON QS UNIVERSITY RANKING: ASIA 2011-2013

\begin{tabular}{|l|l|l|ll|}
\hline \multicolumn{3}{|c|}{ Rating } & \multicolumn{2}{|c|}{ Universities } \\
\hline \multicolumn{1}{|c|}{$\mathbf{2 0 1 1}$} & $\mathbf{2 0 1 2}$ & $\mathbf{2 0 1 3}$ & \multicolumn{1}{|c|}{} \\
\hline 50 & 59 & 64 & University Of Indonesia & \\
\hline 98 & 113 & 129 & $\begin{array}{l}\text { Bandung Institute Of Technology } \\
(\text { ITB })\end{array}$ \\
\hline 80 & 118 & 133 & Universitas Gajah mada & \\
\hline 86 & 135 & 145 & Airlangga University & \\
\hline 134 & $181-190$ & $201-250$ & Bogor Agricultural University \\
\hline $151-160$ & $251-300$ & $201-250$ & Diponegoro University & \\
\hline 128 & $181-190$ & $201-250$ & Padjajaran University & \\
\hline $201+$ & - & $201-250$ & University Of Brawijaya & \\
\hline $201+$ & $301+$ & $251-300$ & Pelita Harapan University & \\
\hline $181-190$ & $301+$ & $251-300$ & $\begin{array}{l}\text { Sepuluh Nopember Institute Of } \\
\text { Technology }\end{array}$ \\
\hline
\end{tabular}

However, The Rector of Bina Nusantara, Harjanto Prabowo believes that achieving the ranking is not difficult, the difficult is to defend it. For example, the reputation of lecturers and students. In addition, he also added the importance of branding in the publication to the world. It will boost the level of popularity that indirectly may attract the attention of the world while inviting foreign students to study in Indonesia. Moreover, many people want to learn the business and culture in Indonesia. In line with that expressed by Riri Fitri Sari, Head of Development Services and Information Systems UI that environment, the atmosphere, the media, and the government has an important role in internationalization. The proportion of foreign students adds value to "sell" the university [13]

The facts show that there is a problem on brand value of higher education in West Java. The brand value is an estimation of the impact of branding on future profits [14]. The brand value is a measure of the net cash flow difference today from another competing brand which is less known or even unbranded. Correspondingly, brand value captures the premium market approach for strong brand over the weak [15]. Meanwhile, according to Interbrand's leading management company that the brand value as the net present value of the expected profit generated by the brand in the future and believe that both marketing and financial analysis are equally important in determining brand value [16].

The key to creating a brand, according to the AMA definition, is to be able to choose a name, logo, symbol, design packaging, or other characteristics that identify a product and distinguish it from others. Different component of the brand that identifies and distinguishes is the brand elements. Branding elements come in various forms [17].

A logo will only mean something if the companies have meaning for that person. As a visual image in the brain, the logo will be a magnet for someone's personal experience with a brand. Logo can trigger memories, opinion, rumor, or a personal experience with a brand. So it is important for us to understand what is being communicated by our logo, either as a separate symbol - for new customers - and as well as a consistent picture of our brand. Only then can we know whether the logo helped in communicating value of the corporate or not. The point is not whether the logo is good or bad, but does it help us to achieve the goal of our brand. There are many ways to compensate the weakness of logo, but first we need to be aware of the strengths and weaknesses associated with the overall direction of the brand. The overall appearance, shape, size, or type of material can also generate an overview of our brand. Unique products can communicate brand personality, set of values, and in many ways, a brand message that speaks louder than can be done by print ads or TV ads whatsoever [18].

Kent Wertime [19] also argues that one of the prerequisites formation of loyalty is the creation of preference. Brands are actually quite effective influence "taste" of products in the consumer's mind. Mysterious thing called "brand value" distinguishes a brand from competitor brands and influencing consumer preferences towards countless product categories. Forecast the future: in the future, building a distinctive brand and the value of the brand will be a key activity in the image. Companies will have to place a greater focus on managing intangible assets.

In addition, according to Kotler and Keller [16] the process of creating brand value is assumed to begin when companies invest in marketing programs that target actual or potential customers. Each investment marketing program that can be attributed to the development of brand value, intentionally or not, are divided in this category-product research, development and design, trade or intermediary support and marketing communications.

The marketing mix is a combination of products, distribution systems, pricing structure and promotional activities [20]. Marketing mix is the set of tactical marketing tools, product, price, place, and promotion-that the firm blends to produce the response it wants in the target market [21].

Here are some of the marketing mix programs conducted by universities in West Java like UNPAD that after several meetings with the leadership of the faculty, eventually UNPAD does not require free disabilities in SNMPTN 2014. That is, those who have a physical disability may apply to the entire faculty offered by UNPAD. Vice Rector for Learning and Student Affairs, Prof. Dr. H. Engkus Kuswarno, M: S said that originally, the entire study program (45 study programs) still requires a student with no disabilities (free of disability or physical disability candidates cannot register). In a letter dated March 10, 2014, 21 study program in UNPAD are still giving free color blind condition to registration in SNMPTN 2014 [22].

Private Higher Education (PTS) in West Java will be allocated the development funds for the New Lecture Hall (RKB) from the Government of West Java Province. For 2013, the Governor of West Java plans to allocate Rp 300 million for each PTS in West Java, which amount to more than 350 institutions. In a total of approximately USD 100 billions. These funds can be used to make three new lecture halls. The program is a continuation of improving the quality of education in West Java, especially the construction of the New Lecture Hall [23].

A total of 30 universities in West Java and West Java provincial government signed an MoU for thematic Field Work Experience program (KKN). The signing was done by 
West Java Governor Ahmad Heryawan and college leadership. Thematic KKN orientation is a focused program of activities to address the chronic problem that needs solving through 40 thematic activities [24].

Based on this background, it is necessary to research on: Effects of Marketing Mix Elements Brand and Brand Values Against Educational Services College in West Java.

\section{METHOD}

In this study, independent variables are Brand Element, which was formed through the Brand Name, URLs (Uniform Resource Locator), Logo and Symbol, Character, tag line (or slogan) and Brand Story. Marketing Mix Education Services which was formed through the Programme, Prospectus, Price, Prominence, People, Promotion and Premiums. As for the dependent variable (the dependent variable) is the brand value created through the Financial, Trusted Reputation, Organizational, and Societal Relevance.

Based on the research objectives, this research is descriptive and verification with the research method used is explanatory survey method and in terms of the span of time (time horizon), the study was classified as cross-sectional studies, collection of data from respondents was conducted in 2014.

Statistical test used Structural Equation Modeling (SEM). The population in this study were active students from 20082012 at public and private universities in West Java, as many as 540087 students with a sample size of 400 respondents. The proposed hypothesis the author as follows:

Brand marketing mix elements and education services do not affect the brand value of higher education either simultaneously or partially (H0: $\gamma 1.1, \gamma 1.2=0)$

Brand Element and marketing mix educational influence on the brand value of higher education either simultaneously or partially $(\mathrm{H} 1: \gamma 1.1, \gamma 1.2 \neq 0)$

\section{RESULTS AND DISCUSSION}

\section{A. Descriptions of Brand Elements of Higher Education in West Java}

Element of the brand is a visual devices and sometimes physical shape that serves to identify and distinguish products or services of the company [25]. Brand element is the trade name paraphernalia that identifies and differentiates the brand [16]. Brand element, sometimes called brand identities, are those trademarks able devices that serve to identify and differentiate the brand [17].

Overview of brand element universities in West Java consists of six elements, i.e.: Brand Name, URLs, Logos and Symbols, Characters, tag line (or slogan) and Brand Story with the following criteria: Memorable, Meaningful, Likable, Transferable, Adaptable, and Protectable [16][17].

Based on the data obtained in the field, most student opinions for memorability and meaningfulness criteria were high on the dimension of brand name and likebility criteria for dimension of logos and symbols. As for the criteria of transferability and adaptability, the most rated dimensions are tag line (or slogan) and in protect ability criteria is the brand story dimension. The score of student responses for the brand elements of universities in West Java is 50542 compared to the ideal score is 72,000 for 36 items of questions, then the brand elements' colleges in West Java were considered in high category for the level of ability to build the brand through the use of brand elements, and it showed that the university has its value to the student in West Java, as expressed by Keller [17] that "Brand element that makes a positive contribution on brand equity will show associations or certain value response."

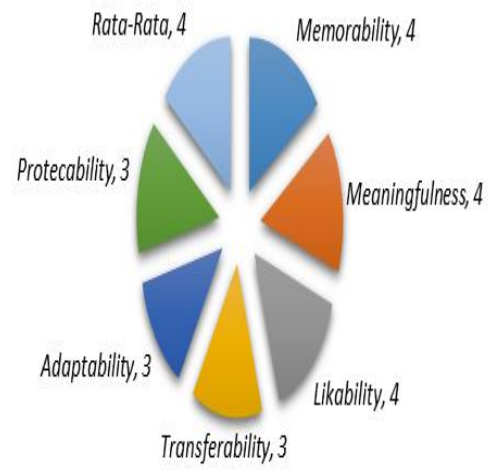

Fig. 1. Overview of Brand Element Of University in West Java

The level of fulfillment of selection criteria of brand elements college in West Java for a memorable, meaningful and likable is in the high category with an average of 4 . This shows that the college's brand construction in West Java is high in terms of how the brand equity can be built through a wise choice of the elements of the brand. As for the criteria of selection of brand elements transferable, adaptable, and protectable category is quite high with an average of 3 in terms of how the brand equity inherent in the brand elements can be improved and sustained in the face of opportunities and limitations as expressed by Keller [17] that "The first three criteria-memorability, meaningfulness and likability-are the marketer's offensive strategy and build brand equity. The latter three, however, play a defensive role for leveraging and maintaining brand equity in the face of different opportunities and constrains "

The first three are able to remember (memorable), means (meaningful) and preferred (likable) is "building a brand." The latter three are can be transferred (transferable), can be customized (adaptable) and can be protected (protectable) is a criterion of "defensive" and relates to the way it affects and protects brand equity in the face of opportunities and limitations [17].

\section{B. Description of Service's Marketing Mix of Higher Education in West Java}

Marketing mix in turn, aims to translate the brand expression into actual products or services, at a specific price, which will be sold in a specific outlet, to be promoted through communication activities and channels, and also must be 
supported by a particular service [26]. The marketing mix is a set of controlled marketing tools used by institutions to manufacture/produce the desired response from the various target markets [27].

The education service-marketing mix is the elements of educational organization that can be controlled by the organization in communicating with learners and will be used to satisfy learners [28]. Description of education Services Marketing mix is done through six dimensions, namely Programme, Prospectus, Price, Prominence, People, Promotion and Premiums [27].

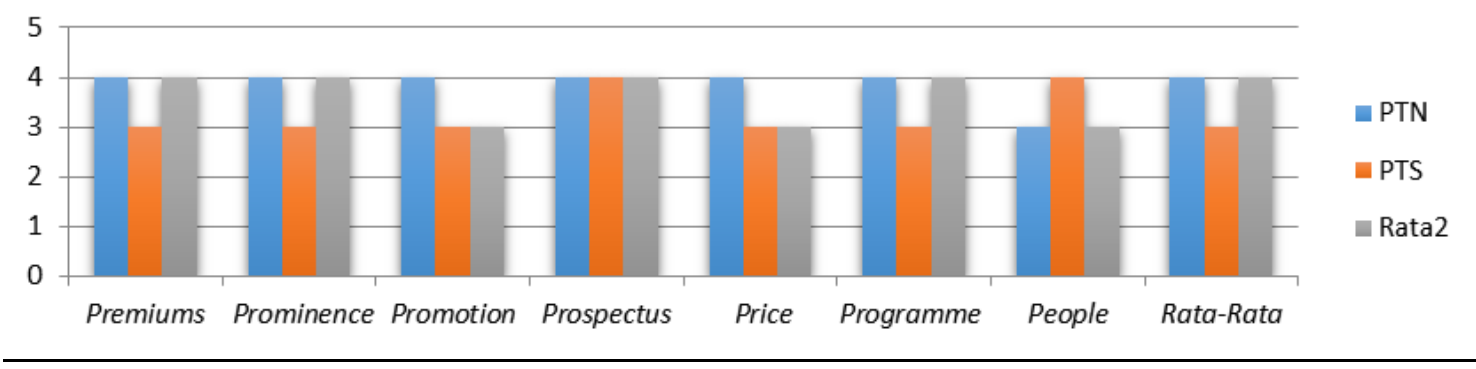

f. Source: Result of Processed Data

Fig. 2. Overview of Educational Service Marketing Mix Of University in West Java

Based on obtained data, high value is achieved in student accommodation (places of worship, cafeteria, dormitories, etc.) on the dimensions of premiums, the ratio of qualified lecturers S2, S3, Professor for prominence dimensions, the use of electronic media in promoting higher-education in the dimension of promotion, the use of the prospectus / brochure in promoting higher-education on the dimensions of the prospectus, and the availability of service-learning face to face in class on the dimensions of people. While the level of conformity duration / length of studies with national standards of higher education on the dimensions of price and variety selection in college education on the dimensions of the program valued quite highly by students.

The score from student's student's response to the marketing mix of college education in West Java, is 34 132, if it compared to the ideal score of 48,000 from 24-item questions, the marketing mix of college education in West Java were considered high; this means that the use and/or implementation of the marketing mix services in higher education in West Java meet the needs and desires of students. Students can use the IT infrastructure or full accommodation in the college environment. Completeness of library books and their online system easier for students to find the necessary materials, tuition payment systems, a variety/variation of education and department or program of study, and so on.

The marketing mix is a set of controlled marketing tools used by institutions to manufacture/produce the desired response from the various target markets [27]. Meanwhile, according to Buchari Alma and Ratih Hurriyati [28] that the marketing mix of education are educational organization's elements that can be controlled by the organization in

A logo will only mean something if our companies give meaning to the person. As a visual image in the brain, the logo will be a magnet for someone's personal experience with a brand. Logo can trigger memories, opinion, rumor, or a personal experience with a brand. It is important for us to understand what is being communicated by our logo, either as communicating with learners and will be used to satisfy learners.

\section{Effects of Brand Elements and Marketing Mix Educational Service on Brand Values of Higher Education in West Java}

The test results showed that the level of Brand Value (NM) is positively influenced by the level Brand Element (EM) and Educational Services Marketing Mix (BPJP), it can be seen from the path coefficient value $(\mathrm{SRW})>0$. The magnitude of the effect of Brand Elements (EM) and the Marketing Mix Education Services (BPJP) to Value Brand (NM) respectively 0.222 and 0.341 at $57 \%$ the level of variation that occurs in Brand Values (NM) can be explained jointly by Element Brand (EM) and Marketing Mix Education Services (BPJP). The remaining $43 \%$ is the influence of other variables that are not described in the model. Estimated structural equation model Brand Value (NM) are:

$$
\mathrm{NM}=0.222 \mathrm{EM}+0,341 \mathrm{BPJP}+0.43 \mathrm{z} 3 ; \mathrm{R} 2=0.57
$$

The effect of brand elements (EM) to brand value (NM) of higher education in West Java is shown by analyzing the value of regression (regression weights analysis of structural equation modeling) where $\mathrm{CR}$ and the $\mathrm{P}$-value of the data are compared with statistical value required, which are for $\mathrm{CR}>$ 1,978 and for a value of $\mathrm{P}<0.05$. Influence of Brand Element (EM) to Brand Value (NM) has the standardized estimate (regression weight) of 0.222 or $22.2 \%$ with CR 2, 066> 1,978 and $\mathrm{P} 0,039<0.05$, which means that Brand Element (EM) significantly influenced brand value (NM). The positive value shows that universities that well considered its brand elements in general tend to have a better brand value.

a separate symbol-for new customers - as well as a consistent overview of our brand. Only then can we know whether the logo help in communicating [18]. 
TABLE V. DIRECT EFFECT OF BRAND ELEMENT AND EDUCATIONAL SERVICE MARKETING MIX TO BRAND VALUE

\begin{tabular}{|c|c|c|c|c|}
\hline & \multirow[t]{2}{*}{ Direct Effect } & \multicolumn{2}{|c|}{ Indirect effect through } & \multirow[t]{2}{*}{ Total } \\
\hline & & $E M$ & BPJP & \\
\hline $\mathrm{NM} \leftarrow \mathrm{EM}$ & 0.222 & - & - & 0.222 \\
\hline $\begin{array}{ll}\mathrm{NM} \\
\mathrm{BPJP}\end{array}$ & 0.341 & - & - & 0.341 \\
\hline
\end{tabular}

g. (Source: Processed Data)

What we want to communicate to "help us communicate" what "helps us communicate what we want to communicate?" Say we have established that innovation is an important part of our core message. Innovation is the principle that drives our company and an important character that we look for our new employees. But, when observing our logo, we concluded that the logo looks dull, old-fashioned and unimaginative. It became less profitable as the company grows, because the logo does not communicate what we want to communicate. In fact, the logo is exactly the opposite of our core messages and becomes a visual reminder of how "not innovative" the company is. It may actually cause problems with potential customers who are not familiar with our company. It can also be a problem whenever our logo appears without additional information from TV ads, brochures, or annual reports that maybe highlight the innovation of our company.

The point is not whether the logo considered to be good or bad, but the logo does help us to achieve our brand objectives. There are many ways to compensate for the weakness of our logo, but first we need to be aware of the strengths and weaknesses associated with the overall direction of the brand. The overall appearance, shape, size, or type of material can also generate an overview of our brand. Unique products can communicate brand personality, set of values, and in many ways, a brand message that speaks louder than can be done by print ads or TV ads whatsoever [18].

Brands are actually quite effective influence to the "taste" of products in the consumer's mind. Mysterious thing called "brand value" distinguishes a brand from competitor brands and influencing consumer preferences towards countless product category. Forecast the future: in the future, building a distinctive brand and the value of the brand will be a key activity in the image. Companies will have to place a greater focus on managing intangible assets is [19].

The influence of marketing mix education services (BPJP) to brand value (NM) universities in West Java is shown by analyzing the value of regression (regression weights analysis of structural equation modeling) where $C R$ and the $P$ value results if the data is compared with statistical value required namely $\mathrm{CR}>1,978$ and $\mathrm{P}<0.05$. Influence of Marketing Mix Education Services (BPJP) to Brand Value (NM) has the standardized estimate (regression weight) of 0.341 , or $34.1 \%$ with CR 6.098> 1.978 and *** $\mathrm{P}<0.05$, which means the Education Services Marketing Mix (BPJP) significantly affects the Brand Value (NM). A positive value indicates that the university has considered a good service education marketing mix in general tends to have a better brand value.

Several universities in West Java are still relying on price as one of the strategies to develop a brand whereas according A.B. Susanto [29] that although the brand has long had a role in commerce, but only in the 20th century, the brand and the interpretation of the brand is so important for business people in the competition. The unique characteristics of modern marketing relying on brand creation discriminatory. Marketing research conducted to help identify and develop the basics for the brand differentiator. The interpretation of a unique brand has strengthened the use of various product attributes, name, packaging, distribution strategies, and advertising. The idea has shifted from commodities towards branded products, thus reducing the importance of price in purchasing decisions.

The brand value calculating future productive attributes of a brand over expected product life cycle, which then appreciated until now. The basic assumption underlying this is that brand owners do not own the brand but to pay for its use, such as in the licensing contract. In this way we can measure the actual commercial value of the brand. This value is based on parameters such as customer satisfaction, brand preference, perception of quality, value for money and good service [30].

\section{CONCLUSIONS AND RECOMMENDATIONS}

Based on the description above, the authors conclude that: (a) brand elements of higher-education in West Java rated high in skill level to build the brand through the use and/or utilization of brand elements, (b) marketing mix college education in West Java rated high, meaning that the use and/or implementation of the marketing mix in higher education in West Java meet the needs and desires of the students, and (c) brand element and marketing mix of educational services affect the value of the brand, which the marketing mix of education has more influence when compared to the dominant influence of the brand element in enhancing the brand value of higher education. Dimension prospectus, people, promotion, program and prominence give dominant contribution.

Suggestions that may be submitted are: (a) university in West Java is expected to continue to increase the use of brand elements such as the use of URL colleges usually a direct translation and perhaps even literally from the brand name, the strengthening tag line or slogan, and strengthening the character of college that is difficult to replicate but can be formed from the culture created by the people who were in it, (b) Universities and college in West Java are expected to continue to improve marketing programs and implementation/performance college.

\section{REFERENCES}

[1] Drost, J, (Dalam Prisma No. 1 Tahun 1990), Untuk Apa Perguruan Tinggi Didirikan, Jakarta: LP3ES, 1990, p124.

[2] Rudd, D., \& Mills, R, Expanding Marketing Principles For The Sale Of Higher Education. Contemporary Issues In Education Research, Third Quarter 2008, Volume 1, Number 3.

[3] Pangkalan Data Perguruan Tinggi Direktorat Jenderal Perguruan Tinggi, http://pdpt.dikti.go.id/, Date Accessed On June 01, 2013 At 10.00 AM

[4] Pikiran Rakyat (Magazine) on 08 April 2010

[5] Pangkalan Data Perguruan Tinggi Direktorat Jenderal Perguruan Tinggi, http://pdpt.dikti.go.id/, Date Accessed On February 15, 2014 At 01.00 PM 
[6] Cimincrang (GM), 55 PTS di Jabar Kondisi Kritis, http://www.klikgalamedia.com/55-pts-di-jabar-kondisi-kritis, Date Accessed On September 16, 2013 At 11.30 AM

[7] A.Mohammad BS, Aneka Strategi PT Lokal Menjawab Tantangan PT Asing, Majalah SWA No. 20/XXVII/Tanggal 22 September - 2 Oktober 2011. pp 100. Jakarta: Sembada Swakarya.

[8] http://www.manajemenpendidikantinggi.net/index.php/component/conte nt/article/11-rubrik2/72-tema-1-isu-4-budaya-dosen-dan-budayaorganisasi-perguruan-tinggi, Date Accessed On July 16, 2014 At 12.00 AM

[9] http://www.manajemenpendidikantinggi.net/index.php/component/conte nt/article/11-rubrik2/72-tema-1-isu-4-budaya-dosen-dan-budayaorganisasi-perguruan-tinggi, Date Accessed On July 16, 2014 At 12.00 AM

[10] Edi Subkhan, Sebuah Studi Analisis: Mempertanyakan Orientasi World Class University*, Disampaikan Pada Seminar Nasional BEM FE Unsoed, 30 Oktober 2010, http://ardianumam.web.ugm.ac.id/?p=2241, Date Accessed On July 16, 2014 At 13.30 AM

[11] QS World University Rankings, http://www.topuniversities.com, Date Accessed On April 12, 2015 At 11.00 AM

[12] QS World University Rankings, http://www.topuniversities.com/university-rankings/asian-universityrankings/, Date Accessed On July 17, 2014 At 13.00 PM

[13] m.sindoweekly-magz.com, 16 nd year, 20 to 26 June 2013

[14] Michael Burger, Brand Equity and Brand Value: Explanation and Measurement. Norderstedt: Books on Demand, 2012, p4.

[15] John. A Davis, Competitive Success: How Branding Adds Value, UK:John Willwy \& Sons. Ltd, 2010, p16.

[16] Kotler, P., \& Keller, K. L, Manajemen Pemasaran Edisi Ketiga Belas, Jakarta: Erlangga, 2009, p277.

[17] Keller, K. L, Strategic Brand Management: Building, Measuring, and Managing Brand Equity, England: Pearson Education Limited, 2013, p30.

[18] Moser, M, United We Brand: Menciptakan Merek Kohesif Yang Dilihat, Didengar, dan Diingat. Jakarta: Erlangga (Indonesian Translation), 2008, p96-97.
[19] Kent Wertime, Building Brands \& Believers: Membangun Merek \& Pengikutnya, Jakarta: Erlangga. (Indonesian Translation), 2003, p14-15.

[20] Ashok Jain, Principles of Marketing, India. V.K.New Delhi: Enterprises, 2009, p77.

[21] Kotler, P., \& Amstrong, Principles Of Marketing 14ed, USA: Pearson Education, 2012, p76.

[22] Kementerian Riset, Teknologi dan Pendidikan Tinggi, Koordinasi Perguruan Tinggi Swasta Wilayah XII Maluku, 2014, Unpad Cabut $\begin{array}{llll}\text { Syarat } & \text { Bebas } & \text { Difabel untuk } & \text { SNMPTN. }\end{array}$ http://www.kopertis12.or.id/2014/03/21/berita-edukasi-20-maret2014.html, Date Accessed On July 10, 2014 At 01.41 PM.

[23] Pemerintah Propinsi Jawa Barat, Heryawan Siapkan 100 Miliar Bangun RKB PT, http://www.jabarprov.go.id/index.php/news/5447/Heryawan_ Siapkan_100_Miliar_Bangun_RKB_PTS, Date Accessed On March 19, 2014 At 03.00 PM.

[24] Pemerintah Jawa Barat Dan Perguruan Tinggi Tandatangani Mou Program Kuliah, 2011, Diposkan oleh M. Denis Caesar, http://braderdennis.blogspot.co.id/2011/12/1321.html, Date Accessed On July 18, 2014 At 02.00 PM.

[25] Kotler, P., \& Pfoertsch, W, B2B Brand Management, Jerman: Springer, 2006, p92.

[26] Sicco Van Gelder, Global Brand Strategy, US: Kogan Page Limited, $2005, \mathrm{p} 1$.

[27] Ivy, J. (2008). A New Higher Education Marketing Mix: The 7Ps For MBA Marketing. Birmingham City University. Birmingham UK. International Journal Of Educational Management Vol. 22 No. 4, 2008 pp. 288-289 @ Emerald Group Publishing Limited.

[28] Alma, B., \& Hurriyati, R, Manajemen Corporate dan Strategi Pemasaran Jasa Pendidikan, Bandung: Alfabeta, 2008, p154.

[29] A.B. Susanto, Himawan Wijarnako, Power Branding: Membangun Merek Unggul dan Organisasi Pendukungnya, Jakarta: Quantum Bisnis \& Manajemen. PT Mizan Publika, 2004, p8.

[30] Nandwani, Ikhsu (Various Author), The New Age Marketing Book, PresoGuru,

p81-82. 